\title{
Capital Market Union and residential capitalism in Europe: Rescaling the housing-centred model of financialization
}

\author{
Rodrigo Fernandez \\ KU Leuven, Belgium \\ Manuel B. Aalbers \\ KU Leuven, Belgium
}

\begin{abstract}
This article examines the effects of implementing the proposals of the European Commission to institute a Capital Market Union (CMU) on the diverse landscape of residential capitalism in Europe. The CMU will bypass existing national institutional blockades that left core countries of the Eurozone, namely Germany, France and Italy, largely untouched by the housing-centred financialization that developed in countries like Spain, Ireland, the UK and the Netherlands. It is widely acknowledged that the rise in securitized mortgage debt contributed to the global financial crisis. As part of the $\mathrm{CMU}$, the new European Commission is promoting mortgage securitization throughout the EU and thereby rescaling the political economy of housing finance that was hitherto rooted in national, institutional models. We argue that countries which 'missed' the previous housing boom will not be able to prevent future housing-centred financialization. CMU thus signifies a spatial expansion of the debt-led accumulation model.
\end{abstract}

\section{Keywords}

Financialization, securitization, housing, Capital Market Union, mortgage markets

\section{Introduction}

The global financial crisis that started in 2007 was, at least in part, triggered by the preceding boom in house prices. House prices did not rise primarily as a result of increasing income or decreasing availability, but as a result of the increasing availability of mortgage finance, caused by low interest rates, mortgage securitization and, in some countries, the rise of new types of lenders, which together enabled increasingly more households to take out

\section{Corresponding author:}

Rodrigo Fernandez, Department of Geography and Tourism, KU Leuven, Celestijnenlaan 200E Box 2409 , 3001 Leuven, Belgium. Email: rodrigo.fernandez@kuleuven.be 
increasingly larger mortgage loans (Aalbers, 2008). In other words, the boom was part of a housing-centred model of financialization which relied on increasing household indebtness to fuel economic growth (Fernandez and Aalbers, 2016).

In recent years, house prices and debt levels have started to rise again in most of the countries that were heavily affected by national housing crises. Notwithstanding that in the aftermath of the crisis, securitization and shadow banking more broadly were widely perceived to create systemic risks (European Commission, 2012; FSB, 2011; Pozsar et al., 2012; Turner, 2012), the European Commission (EC) has recently decided to promote mortgage securitization as a safe and efficient channel for credit intermediation (European Commission, 2015a). The final securitization plan, which is part of the Capital Market Union (CMU) proposal, labels securitization as "simple, transparent and safe" (STS) (European Commission, 2015b). We argue that in the CMU proposal, "securitization" at-large is discursively rebranded as "high-quality securitization" (European Commission, 2015a).

The CMU is a patchwork of over thirty legislative fragments and policy interventions, accompanied by an ambiguous storyline revolving around the need to create new structures for capital intermediation in the EU to finance small- and medium-sized enterprises (SMEs) as well as long-term investments, and to revive the EU economy. Critical examinations of the proposal (Engelen and Glasmacher, 2016; Mueller, 2015) stress that SMEs have been made part of the $\mathrm{CMU}$ to provide political legitimatization and have little to do with the actual rationale behind the proposal.

A second storyline associated with the $\mathrm{CMU}$ is the alleged overreliance on banks as financial intermediaries in the EU and an aspiration to emulate the US, where capital markets have a stronger position in the overall financial structure. Particularly in the post-crisis setting, with EU banks still repairing their balance sheets and relying on ECB liquidity facilities for funding, a deeper pan-EU capital market is required to provide an alternative financial channel, according to the EC. At the centre of the $\mathrm{CMU}$ is a goal to remove national barriers to enable the free movement of collateral. The flagship of the range of proposals gathered under the $\mathrm{CMU}$ label is the securitization proposal, which is about housing finance rather than lending to SMEs. This article will focus on the securitization aspect of the CMU.

Mortgage securitization is a US state invention (Gotham, 2009; Immergluck, 2009), and research has demonstrated that the roll-out of securitization to other markets and countries has required an active role for the state in restructuring housing finance and establishing viable secondary mortgage markets (Aalbers et al., 2011; Wainwright, 2009, 2015; Walks and Clifford, 2015). In historical perspective, the $\mathrm{CMU}$ is the next step in the rolling-out of securitization. As we will argue, the $\mathrm{CMU}$ will have the effect of rescaling the secondary mortgage market - i.e., the market for securitized mortgages - from one embedded in national housing and finance institutions, some more financialized than others, into a pan-EU market in which national housing finance will increasingly rely on mortgage securitization. This implies that what we call 'housing-centred financialization' will become the default option throughout the EU and differences between national housing finance systems will be reduced, resulting not only in the roll-out of securitization throughout the EU but also in the rise of mortgage-debt-to-GDP ratios in many countries as well as at the EU level.

Housing-centred financialization refers to a particular reading of financialization that is focused on how, since the 1980s, and especially in the last twenty years, residential real estate has on the one hand come to function as a principal store-of-value for households but on the other, is increasingly accessible only through the availability of ever-larger mortgage loans, an increasing number of which are repackaged and sold as mortgage-backed securities (Fernandez and Aalbers, 2016). Real estate, and housing in particular, functions as a key 
source of collateral, not only for mortgage loans and mortgage-backed securities, but for a whole range of financial products that ultimately rely on the value of underlying housing units.

The Regulation Approach sees growing household debt as part of a 'finance-dominated accumulation regime' (Boyer, 2000; Stockhammer, 2004). Crouch (2009) views this as a distinctive policy regime he has labelled 'privatized Keynesianism', in which private debt replaces public debt as the main demand management mechanism to stimulate the economy. Along similar lines, Schwartz (2012) points to the central role of housing wealth-based consumption in the transformation of the political economy. During the boom years, mortgage credit enabled sustained consumption in the face of a lower wage share. Worldwide, the wage share declined from 63\% of global output in 1980 to 54\% in 2011 (UNCTAD, 2013). The housing bubble masked an unequal allocation of wealth between labour and capital. This debt-led and housing-centred form of financialization is part of a larger reshuffling of risks from collectively organized arrangements by and through the state towards households and through financial markets (Engelen, 2008; Hacker, 2008; Martin, 2002). The penetration of daily life by financial logics is also veiled under an 'ideology of homeownership', which accompanied the initial increase in mortgage-debt-to-GDP ratios (Ronald, 2008; Aalbers and Christophers, 2014).

In this article, we argue that the CMU will allow collateral and particularly residential real estate that is currently embedded in national, institutional settings, to 'jump scale' and be absorbed by supranational shadow banking structures, significantly increasing its liquidity on global markets. Although we do not argue that pushing mortgage securitization is the key objective of the $\mathrm{CMU}$, we believe that mortgages will be the main product to securitize under conditions of the new EU framework, either as intended or unintended consequence. This assumption is based on the current weight of mortgages in the overall market for securitization, combined with the absence of restrictions on the type of collateral elligble for the STS label. The CMU has the potential to change the map of housing finance in the EU by providing alternative, supranational routes to extend mortgages. It represents a deepening of the financialization of housing in the EU. The question is how will this affect existing housing regimes rooted in different institutional models of capitalism (Schwartz and Seabrooke, 2008). While some economies have high to extremely high mortgage-debt-to-GDP ratios, like the Netherlands, Denmark and the UK; others, such as Germany, Italy, France, and Austria, remain relatively untouched by securitization and ballooning mortgage debt.

In the next section we introduce the concept of housing-centred financialization. We then provide a stylized overview of the diversity of housing finance models in the EU in order to highlight the uneven nature of housing-centred financialization. Finally, the expected consequences of the CMU, and in particular the STS proposal for mortgage securitization, will be discussed. Our argument contributes to debates on the CMU and the changing nature of the socio-economic governance of the EU more broadly. It also contributes to the literature that centres housing in political economy debates by showing how housing is a key domain of financialization in both empirical and political terms. Fundamentally, the article shows the interrelatedness of shifts in national housing systems and the politics of finance at the level of the EU, thereby speaking to comparative institutionalism and varieties of capitalism scholars.

\section{The housing-centred model of financialization}

The renewed centrality of housing to the political economy (Aalbers and Christophers, 2014) is part and parcel of the swing of Polanyi's pendulum of embedding and disembedding markets 
(Polanyi, 2001/1944). The demise of Keynesian embedded liberalism in the 1970s created scope for a neoliberal "political project to re-establish the conditions for capital accumulation" (Harvey, 2005: 19). This development started in the 1970s and 1980s, and largely revolved around the state led-reorganization of the dominant model of accumulation based on wages into one based on private debt (Crouch, 2009; Streeck, 2015) - a transformation from a Fordist to a finance-led regime of accumulation (Boyer, 2000; Stockhammer, 2004). The concept of a housing-centred model of financialization is not at odds with other understandings of financialization. In fact, it transcends different conceptualizations of financialization by connecting the finance-led regime of accumulation to the transformation of banks, the securitization of mortgage portfolios, and the financialization of households (Aalbers, 2008). Different understandings of financialization are conceptualized at different scales (the economy, the firm, the household, etc.) in the literature, but are empirically and intrinsically linked, as the case of housing makes clear.

The focus on housing rather than on other sectors has several reasons, as we will demonstrate in this section. First, housing is one of the few sectors that directly connects the global political economy of finance to the fate of households. Second, the lion's share of banks' lending activities these days relates to real estate, and in particular residential real estate. Third, housing, together with sovereign debt, is a key source of 'high-quality collateral' for institutional investors. As the combined capital of institutional investors grows faster than global GDP and sovereign debt from most countries rated as low-risk is not increasing, the need for housing as collateral has increased and continues to increase (Fernandez and Aalbers, 2016). In other words, housing is not simply yet another domain of financialization. In terms of size and impact, it is the key domain of financialization. In that sense the notion of housing-centred financialization is not only a conceptual tool, but also an empirical reality, as we will illustrate below.

The transformation from a Fordist to a finance-led regime of accumulation is also visible in the parallel shift in housing systems, which have moved from social rented housing and social homeownership towards financialized homeownership and privatized rental housing (Aalbers, 2015; Forrest and Hirayama, 2015; Jones and Murie, 2006; Ronald et al., 2015). This change in the dominant type of tenure was accompanied by a strong and persuasive ideological reorientation idealizing the homeownership society (Kemeny, 1981; Ronald, 2008). Furthermore, countries that relied on a housing-centred financialization model - typically the Anglo-American economies, as well as the Netherlands and Denmark - also went further in reregulating their national housing finance systems, introducing new tax incentives and facilitating the securitization of mortgages (Aalbers, 2008; Gotham, 2009; Langley, 2006; Schwartz, 2009).

The new realities of financial globalization, characterized by hypermobile capital, crossborder competition, and the neoliberal re-regulation of markets were increasingly incompatible with large publicly-controlled housing providers that typically were key architects of the postwar housing regimes (Aalbers, 2015; Rolnik, 2013). With the rise of the homeowner society, based on the belief that residential real estate was able to serve as a vehicle to preserve and enlarge private wealth, we saw the rise of 'the indebted man' (Lazzarato, 2011) and 'the return of the rentier' (Hudson, 2012). Rising levels of indebtedness resulted in ever more effective and intrusive disciplining structures, which enabled an increase in the extractive capacity of financial agents (Di Feliciantonio, 2016; Lapavitsas, 2013; Lazzarato, 2011).

To assess the role of housing in the present-day political economic landscape, we need to look at the ballooning balance sheets (assets and liabilities) of financial intermediaries and households in the two decades before the crisis. The total value of housing in the EU in 2011 
was $€ 22.5$ trillion, larger than the market for government bonds (€7.5 trillion) and stock market valuation (€7.2 trillion) combined (EPRA, 2012). EU housing wealth grew at a rate of 9\% per year between 1980 and 2006 (BIS, 2009; ECB, 2006). The largest increase occurred between 1998 and 2006, when housing wealth grew from €13.3 trillion to €23.2 trillion (BIS, 2008). In 2012 the size of mortgage debt in the EU and US was estimated at $€ 6.7$ trillion and $€ 8.2$ trillion respectively (EMF data). Between 1998 and 2011, the mortgage-debt-to-GDP ratios increased from $32 \%$ to $52 \%$ in the EU and from $54 \%$ to $76 \%$ in the US (EMF data).

The increased importance of housing wealth to the economy is also illustrated in Piketty's Capital in the Twenty-First Century (2014), in what he describes as the "metamorphosis of capital'. His data show that in France and the UK, the capital-to-income ratio followed a Ushaped curve in the period from the eighteenth to the twenty-first century. A stable capital stock in the range of $600 \%$ of income throughout the eighteenth and nineteenth centuries was largely based on agricultural land and increasingly from colonial investment outlets. After World War I, the ratio of capital-to-income declined dramatically, only to return from the 1970 s onwards. This return towards a large capital-to-income ratio was largely propelled by real estate, i.e. again based on land, although now predominately on urban rather than agricultural land. From the 1950s to the 1990s, Piketty's data show that housing wealth as share of overall capital remained stable at 40\%, albeit increasing rapidly vis-à-vis income. In the last two decades, however, the size of real estate increased to $58 \%$ of the overall stock of wealth and $300 \%$ of annual income in 2010. In his longue durée account of the transforming composition of capital, Piketty demonstrates that the present-day value of real estate in relation to the overall stock of capital and of income is truly without historical precedent.

Since the 1970s, housing has increasingly become a crucial component in the wider political economy of finance (Aalbers and Christophers, 2014; Schwartz, 2012; Hudson, 2012). Since housing markets strongly react to changes in interest rates, the housing market transmits monetary policies, affecting capital markets and consumer demand. The post-crisis policy of the US Federal Reserve (so-called 'easy money' or quantitative easing) has therefore had profound distributional effects. The sustained policy of low interest boosted real estate prices in the UK and the US by 14\% and 15\% respectively between 2008 and 2013 (McKinsey, 2013). On paper this has created impressive wealth effects, but in reality it has resulted in more-indebted homeowners on the one hand, and a surge in the number of households priced out of homeownership on the other. In other words, low interest rates have not resulted in increased affordability, but have actually made homeownership less accessible, with a drop in the homeownership rates in both countries as a result.

At its core, finance-dominated capitalism or privatized Keynesianism relied on the expansion of housing finance: larger mortgage loans to a larger number of households. Mortgage booms fed housing booms that, in return, contributed to economic growth, as the Dutch National Bank concluded in 2000, at the end of the largest five-year increase in house prices in the Netherlands (DNB, 2000). Economic growth was basically caused by house price inflation (see also Aalbers, 2016; Turner, 2015). As mortgage credit was not automatically rolled out, housing finance markets were adapted to accommodate larger funding streams and therefore larger mortgage volumes. In almost all countries, the existing mortgage regulation was restructured in order to enable, both legally and economically, higher loan-tovalue and loan-to-income ratios, and in some countries equity release schemes and the securitization of mortgage portfolios.

But not only housing finance was transformed. As the importance of it increased, housing finance, in effect, transformed banking. A study based on historical data for 17 selected advanced economies found that the share of mortgage debt in banks' lending portfolios rose 
from 30\% in 1900 to 60\% in 2014 (Jorda et al., 2014). In countries like the UK the increase began in the 1970s, but elsewhere it took place later, beginning in the 1980s and 1990s. In other words, the rise in the share of mortgages in bank portfolios developed during a period in which the size of the banking sector as proportion of GDP swelled to unprecedented heights (BIS, 2012). This period of the 'great leverage' entailed the growth of the stock of bank assets in proportion to GDP in 14 advanced economies towards $200 \%$ of GDP.

This transformation of the banking sector, from providing credit to corporations into extending mortgages and capital market activities, is also in line with the depiction of the 'financialization of capitalism' by Lapavitsas (2013). In his analysis, financialization embodies a systemic reconfiguration of capitalist economies with three interrelated features. Firstly, ever-larger corporations acquired financial capacities of their own and therefore came to rely less on banks. Secondly, banks shifted from financing firms towards capital market transactions and interbank lending. Thirdly, households became increasingly involved in the operations of finance, primarily through mortgage loans. This shift in financing from corporate activities into residential real estate has been reiterated by Adair Turner (2012: 61), former Chairman of the British Financial Services Authority, who has characterized it as "too much of the wrong debt". Turner has argued that the rising importance of real estate in banks' portfolios means that there is a growing stock of unproductive investment. While corporate investment may yield productive returns in the future, investment in (already existing) real estate does not.

These diverse, but interrelated, transformations that range from the rise of homeowner societies, mortgage debt, and growing ties between housing wealth and macroeconomic and monetary policies are condensed in the notion of housing-centred financialization (Fernandez and Aalbers, 2016). Housing is not merely the carrier of the practices of financialization, but a pivotal component of the fragile debt-led accumulation model with systemic linkages. To governments around the globe, the promotion of homeownership through the expansion of mortgage credit became 'addictive' as it allowed political elites to overcome problems sustaining corporate profits by lowering the wage share while increasing private consumption and achieving fiscal surpluses. Even though the great financial crisis clearly demonstrated the limits of the housing-centred model of financialization, the response in a range of countries, including the US, the UK, Ireland and the Netherlands, has been geared towards revitalizing housing markets instead of moving into alternative policies that would encourage deleveraging. Rather than breaking the cycle, the CMU proposal will push even more countries into a housing-centred financialization.

\section{Varieties of housing-centred financialization in the EU}

This section turns to the different degrees of housing-centred financialization in the EU. The hypothesis formulated in the introduction of this article is that the CMU is likely to lead to an expansion of private debt in countries that have not yet become fully entrenched in the model of housing-centred financialization. The latter group of countries includes the main economies of the Eurozone - Germany, France, and Italy - but also countries like Austria and Poland. In fact, all Central European countries (CEEs) and Mediterranean countries (except for Spain) fit this profile (Fernandez and Aalbers, 2016). On the other hand, we find the UK, Ireland, the Netherlands, Denmark and Spain. These economies already have high to very high mortgagedebt-to-GDP ratios, and are unlikely to show the same growth rates of private indebtedness as they have experienced in the last two decades. 
Although we differentiate between countries with relatively low and relatively high levels of private debt, all European countries, except for Germany, moved towards higher debt levels in the last two decades. Figure 1 illustrates this common trajectory: countries moving in the same direction, but from different starting points and at different speeds. The figure compares mortgage-debt-to-GDP ratios in 2000 and in 2010. Whereas in 2000, most countries (except for Denmark, the Netherlands, the UK and Germany) had a debt-to GDP ratio of less than 40\%, we can see how several countries have moved to higher debt levels by 2010. Again, we see Denmark, the Netherlands, and the UK here - but not Germany - as well as Spain and Ireland. Despite sizeable increases in private and mortgage debt in Belgium, France, and Italy, the trajectories of these countries look modest by comparison.

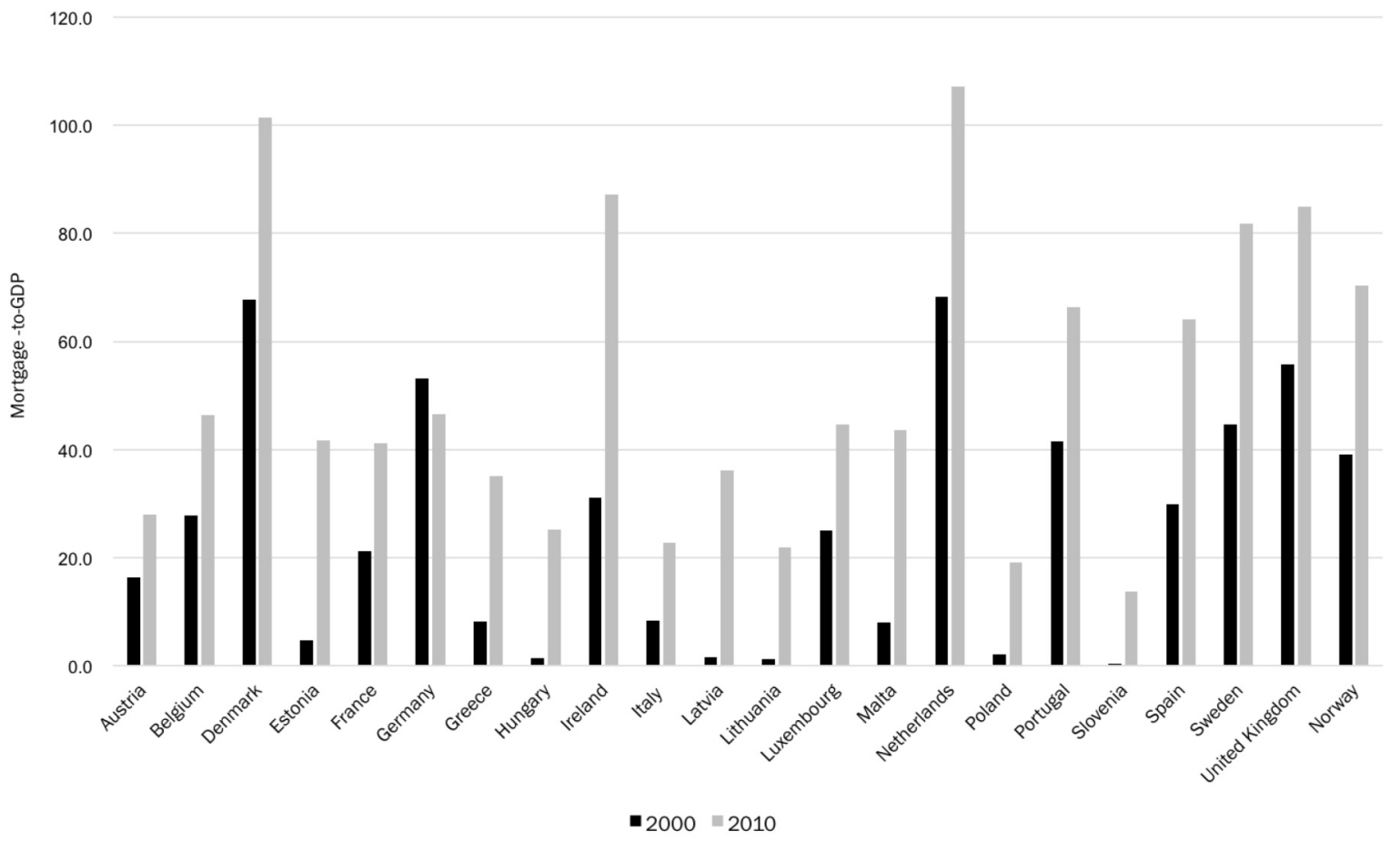

Figure 1. Mortgage-debt-to-GDP ratio in 2000 and 2010 in selected EU countries. Source: EMF, 2015.

Table 1 provides a wider overview of the variegated landscape of residential capitalism in the EU. The low-debt countries all share an absence of mortgage equity withdrawal schemes, have a relatively small nominal stock of securitized assets (except for Italy), and display a low score on the IMF mortgage market index. ${ }^{1}$ The data on securitization can be deceptive in the case of Italy. It has a relatively large stock of securitized assets but these consist largely of corporate bonds. Levels of housing construction are not significantly lower or higher in the low-debt countries. Only Spain and Ireland, the countries that moved the fastest from low- to high-debt, had high levels of construction, visible in the extraordinary increase in the total number of dwellings between 2000 and 2010 (Table 1). Despite significant overbuilding, these two countries saw their housing prices explode prior to the global financial crisis. This illustrates how increasing house prices are not primarily driven by a lack of new construction but rather by the availability of mortgage credit (Aalbers, 2016). 
Table 1. Selected indicators of models of residential capitalism. Sources: Column 1. OECD, 2010; 2. AFME, 2016a; 3. IMF, 2008; 4. Eurostat data; 5. Calculation based on data provided by EMF.

\begin{tabular}{|c|ccccc|}
\hline & $\begin{array}{c}\text { Mortgage equity } \\
\text { withdrawal } \\
2010\end{array}$ & $\begin{array}{c}\text { Outstanding } \\
\text { securitization } \\
2015(€ \text { bn) }\end{array}$ & $\begin{array}{c}\text { Mortgage } \\
\text { market index } \\
2008\end{array}$ & $\begin{array}{c}\text { Home } \\
\text { ownership } \\
\text { rates 2015 }\end{array}$ & $\begin{array}{c}\text { Increase in stock } \\
\text { of dwellings } \\
(2010 / 2000)\end{array}$ \\
\hline Germany & No & 71.2 & 0.28 & 52 & 105 \\
\hline France & No & 70.3 & 0.23 & 65 & N/A \\
\hline Italy & No & 157.2 & 0.26 & 73 & 121 \\
\hline Belgium & No & 69.8 & 0.34 & 72 & 109 \\
\hline UK & Yes & 374.1 & 0.58 & 64 & 108 \\
\hline Spain & Limited & 170.4 & 0.40 & 78 & 132 \\
\hline Ireland & Limited & 35.9 & 0.39 & 69 & 143 \\
\hline Netherlands & Yes & 247.0 & 0.62 & 68 & 109 \\
\hline Denmark & Yes & N/A & 0.82 & 63 & 108 \\
\hline
\end{tabular}

In 2013, the average homeownership rate in the EU-28 was $70 \%$; roughly one-third of this is mortgaged and two-thirds are non-mortgaged (Eurostat data). We can identify two kinds of shifts, although in each country one shift tends to be dominant. In countries like Denmark, the Netherlands, and the UK, we see a strong tenure shift, however not simply from renting to owning, but rather from renting to mortgaged homeownership - in other words, the tenure shift has been enabled by, or effectuated through, mortgage lending. In the UK in particular, the share of social rented housing has decreased and, since the crisis, we see an increase in the private rented sector as homeownership has become less accessible for younger generations (Ronald et al., 2015). Homeownership rates in the UK declined from 74\% in 2007 to $64 \%$ in 2015 (Eurostat data), and the outstanding stock of securitized assets declined from $€ 702$ billion to €374 billion (AFME, 2016a).

In Southern Europe we do not really see a tenure shift: high homeownership rates are sustained. The real shift taking place here is from largely non-mortgaged homeownership to increasingly mortgaged homeownership. We see this to the extreme in Spain, but also on a smaller scale in a country like Italy. Until recently Germany appeared to be the exception, with a moderate but steady homeownership rate and slightly decreasing mortgage debt, but in the last few years, we also see how Germany has started to shift from rental housing to mortgaged homeownership (Wijburg and Aalbers, 2017).

\section{The Capital Market Union and the expansion of the housing-centred model}

The variegated landscape of housing-centred financialization discussed above is basically structured by the disparities in housing finance: the availability and the price of credit. To increase the availability of credit, the $\mathrm{CMU}$ proposes an EU-wide market for collateral, such as residential real estate, and active, top-down, market making. Central to the STS securitization proposal is the lowering of capital requirements for securitized assets, thereby lowering the price of funding for banks and of mortgages. Real estate is by far the largest class of collateral in the EU and US. The stock of securitized assets in the first quarter of 2015 stood at $€ 8.330$ 
billion in the US and $€ 1.336$ billion in the EU. Real estate is the collateral for $€ 7.071$ billion (85\%) of securitizations in the US and €893 billion (65\%) in the EU (EMF data). In this section we will discuss the CMU and the mechanisms through which it will likely expand the geography of the housing-centred model of financialization to countries that currently have relatively low mortgage-debt-to-GDP ratios. We first discuss the critical issues of securitization and then turn to the STS securitization proposal to see how this may impact existing geographies of housing finance and tenure in the EU. While STS securitization is framed as a solution for SMEs, we argue that it could become a policy initiative to fuel mortgage securitization.

\section{The problem with securitization}

It is worth recalling why securitization came to be associated with the largest financial crisis since the Great Depression. Before the crisis, securitization consisted of a chain of actors operating according to the so-called 'originate-to-distribute' model. This model produced a deficient incentive structure insofar as originators, other intermediaries, and related actors (such as credit rating agencies) received remuneration according to the amounts of transactions they processed, disregarding the quality of the underlying loans. The securitization process was indifferent to the real-world characteristics of the collateral, and transferred risks onto end investors and banks that retained securitized assets on their balance sheet. The originate-to-distribute model remains a problem in the CMU proposal even though originators are obliged to retain 5\% of securitized assets. This threshold, fiercely defended by financial market lobbyists, is considered to be massively inadequate by the civil society organisation Finance Watch, which has argued for a threshold of "20\% or more" (Finance Watch, 2016: 2).

In addition, securitization developed alongside and in relation to a broader set of nonbank intermediaries, cohering into a largely unregulated, cross-border market structure known as shadow banking. Although securitization is only a small part of this overall marketplace, an estimated 8\% in 2015 (FSB, 2015: 8), it is an essential channel connecting households to complex shadow banking transactions. Securitization developed as part of this larger chain of intermediaries, and thereby internalized additional governing principles that disregard the quality of the underlying mortgages.

The life-cycle of securitized assets does not simply stop once they are sold to end investors, but are frequently used and re-used as collateral for transactions, i.e. 'rehypothecated', in the shadow banking system (IMF, 2011a, 2011b). Securitized assets are, in effect, transformed into a 'global currency' in the shadow banking system, especially as the shortage of other high quality collateral, such as high grade public bonds, has increased demand for securitized assets (BIS, 2013). This scarcity of alternative, liquid, high quality collateral means that securitized assets, next to sovereign bonds, are permanently in strong demand by shadow banking entities or institutional investors to fuel transactions, such as repos, irrespective of the quality of their underlying collateral. This demand for liquefied mortgages in turn was an impetus for banks to provide more mortgages, as it provided a boost to fee- and commission-based income. Again, this points to flawed incentive structures that only appear in sight once we take the broader context into account.

This environment proved to be remarkably unstable after the bankruptcy of Lehman Brothers. As the shadow banking system operates and connects across separated markets, a change in the valuation of collateral in one market can influence another. Once the market for securitized assets collapsed in 2007, so did its use as collateral in re-hypothecation schemes. The financial crisis revealed that market dynamics of shadow banking were prone to severe 
pro-cyclical behaviour and inherently unstable (FSB, 2012b). If we evaluate the risk of securitization and try to determine what constitutes 'safe' securitization, we therefore need to include its broader systemic linkages through shadow banking transactions, and how demand in these echelons of finance ultimately influence the supply of mortgages.

Another element to include in the assessment of securitization is the transnational nature of European securitization chains. Loans provided in one country may be held on the balance sheet of a special purpose vehicle (SPV) in another country. At the heart of moving assets offbalance is the mobility of collateral across borders. Without this mobility, securitization would be taxed according to the tax regime in the country where the loans originate. Loans with collateral in one country, say mortgages in Italy, can be repackaged in another country, like Ireland, to be listed as bonds on the stock market in a third country, such as Luxembourg, to end up in the portfolio of an asset manager in a tax haven, for instance the British Virgin Islands, all of this being orchestrated by a French bank through its London branch. ${ }^{2}$

This real-world geography of securitization shows that, in practice, the costs for the originator and the investors have been reduced by incorporating a legal entity in an offshore financial centre. Ireland and Luxembourg stand out as the preferred locations for SPVs that retain the assets once they have been moved off-balance in other European countries. There are no withholding taxes for foreign investors, so profits made by SPVs are moved to tax havens (BIS, 2011a; PwC, 2016). Banks use conduits, empty shells, to move loans originated in a third country off-balance into a low-tax environment.

If we compare the amount of securitized loans by the country of origin of the collateral (AFME, 2016a: 11) with the stock of assets held by SPVs (ECB monetary and financial statistics), it appears that Ireland has a 'surplus' of $€ 84$ billion compared to Germany, Spain, and Italy, which have a 'deficit' of €23, €21 and €5 billion respectively in 2015 . Luxembourg, for which there is no data on securitization as country of origin, is home to SPVs with securitized assets worth €84 billion, according to ECB data. Figure 2 displays the distribution of the number of 'securitization vehicle corporations' (this is the ECB classification for SPVs engaged in securitization) in different EU countries. The pattern corresponds to the previous observation that securitization activities in the EU are concentrated primarily in European tax havens such as Ireland and Luxemburg.

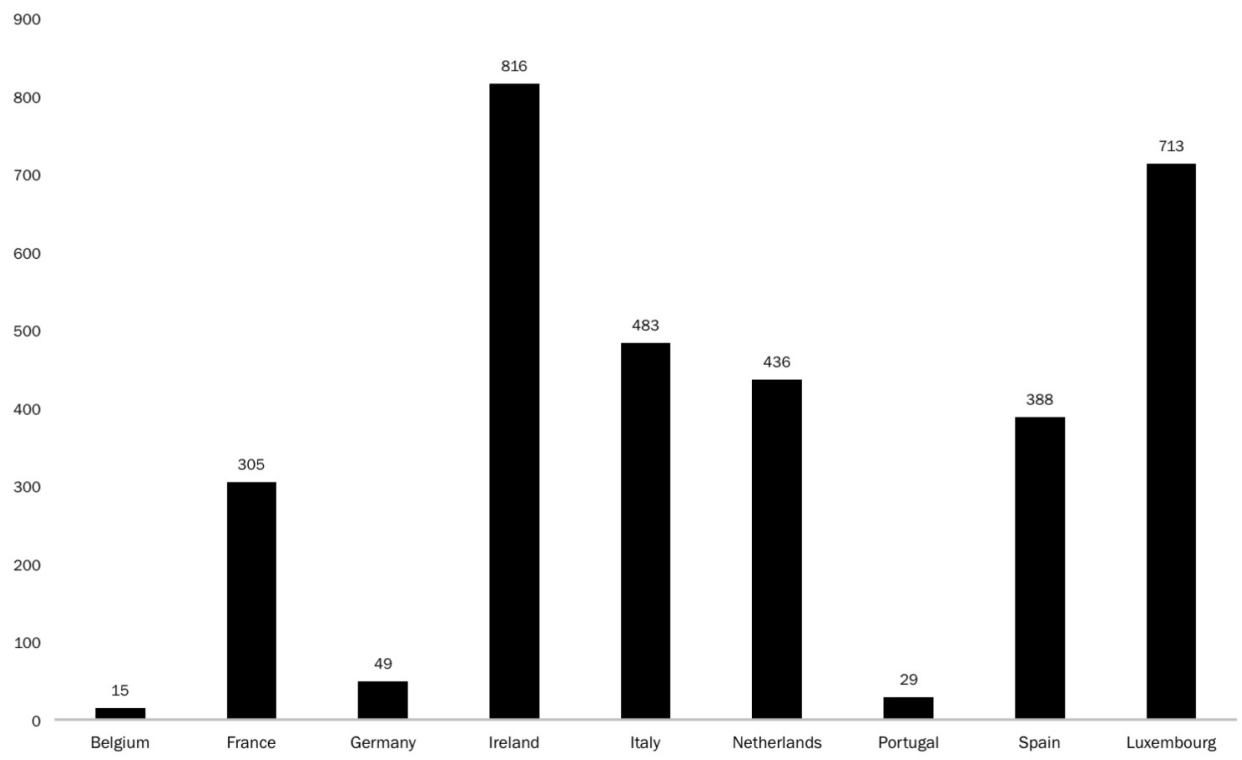

Figure 2. Number of securitization SPVs in 2015. Source: ECB monetary and financial statistics, Financial vehicle corporations data. 
The offshore geography increases the attractiveness of securitized assets for investors as it lowers taxation on capital gains. This in turn lowers the cost of securitization as a funding source for banks relative to deposit funding. This calls into question the need to lower funding costs, as proposed by the STS paragraph of the CMU proposal. The cost difference between these two forms of financial intermediation introduces another layer of flawed incentives. The cheaper form of funding (securitization) relies on the originators' ability to produce liquid bundles of loans and a favourable secondary market environment. The first requirement favours mortgages over other loans (such as SME lending) and the second requirement is met as long as the period of expansionary monetary policy persists. Compared to other types of debt, such as SME lending, car loans, or student debt, mortgages have proven to be the most liquid type of debt. The policy regime of the great moderation allowed for a debt-led accumulation model to come of age that largely centred on housing bubbles (Aalbers, 2015). The current monetary policy of the ECB, which includes the direct purchase of securitized assets, accommodates growing private debt to an even larger extent. This means that incentives to provide loans by banks are not primarily shaped by borrowers but by capital market conditions and monetary policy. This is how loose monetary policies and scarcity of high quality collateral in shadow banking markets inflate housing bubbles: from the top down.

\section{The CMU's 'safe, transparent, and standardized' securitization proposal}

The STS proposal is part of the broader CMU scheme, one of the pillars of the agenda of the Juncker commission that took office in 2014. The CMU is presented as a solution to macroeconomic and financial market problems facing the EU. It is intended to resolve funding difficulties of the SME sector and to expand credit for long-term infrastructure investments, thereby creating jobs in the EU. The EU commission argues, in defense of the CMU, that the anaemic growth of the EU following the great financial crisis and the euro crisis require wellfunctioning debt channels. The weak EU banking system, the EU commission argues, cannot deliver on its own. This calls for a 'second engine', just as in the US, where the mix of financial intermediation relies less on banking and more on capital markets.

Another element of the $\mathrm{CMU}$ discourse from the EU commission is to develop investment opportunities for institutional investors, particularly pension funds. Next to securitization, which directly produces financial assets, the CMU framework intends to harmonize insolvency and tax laws and to standardize accounting standards for non-listed enterprises. The full CMU package aims to increase and institutionalize cross-border capital market developments in Europe. Indeed, one of the core principles spelled out in the CMU green paper is that "it should create a single market for capital for all 28 Member States by removing barriers to cross-border investment within the EU and fostering stronger connections with global capital markets" (European Commission, 2015a: 5).

The STS securitization proposal aims to increase transparency by standardizing the process to differentiate between STS and 'opaque' types of securitization. This state-led market making aims to reduce complexity and create a safer market environment. The EU Commission also points to the difference between the dramatic collapse of the market for securitization in the US during 2008, compared to the modest repercussions on the EU market for securitization in its aftermath. Thereby, the Commission argues that the EU STS proposal is built on safe economic fundamentals compared to the US.

The political narrative employed by the EU commission to navigate decision making in Brussels, however, disregards two crucial contextual elements. Firstly, austerity policies have 
been implemented across the EU. This is important as many EU countries have seen strict austerity measures since 2010, without an exit strategy in place for the conceivable future. This is reflected in a lack of effective demand which plagues the SME sector across the EU. An ECB (2016: 10) survey on the access to finance of enterprises in the euro area concluded:

\footnotetext{
"Finding customers" was the dominant concern for euro area SMEs in this survey period, with $25 \%$ of euro area SMEs mentioning this as their main problem (from $27 \%$ in the previous survey round). "Access to finance" was considered the least important concern (9\%, from 10\%), after "Cost of production" (12\%), "Regulation" (12\%), "Competition" (13\%) and "Availability of skilled labour" (19\%).
}

The same ECB study also shows that European banks have been effective in allocating capital to the SME sector, including providing lower interest rate loans. The point, however, is that even if reviving securitization would bring better credit conditions for the SME sector in Europe, it would not solve the problems troubling this sector, which is the absence of demand related to macroeconomic conditions, and fiscal policies resulting from the institutional architecture of the Euro (Streeck, 2016; Stiglitz, 2016). More credit does not solve this issue: you can lead a horse to water, but you can't make it drink.

Secondly, the unconventional monetary policies of the ECB are missing from CMU debates in Brussels. The ECB's expansionary post-crisis monetary policies radically transformed the securitization landscape of the EU in different ways (Buchanan, 2017). Banks started to retain securitized assets, keeping them on their balance sheet so as to use them as collateral for the ECB's liquidity programmes (OECD, 2011; IMF, 2015). This resulted in a rise in the issuance of retained securitized assets from the crisis onwards, predominantly based on mortgages (OECD, 2011). In 2009 roughly 90\% of all new securitizations in the EU were retained, up from 30\% in 2007 (IMF, 2015: 9). Although the share of retained securitization declined after 2009, it was still around 65\% in the third quarter of 2016 (AFME, 2016b: 4). This shows that the reason for banks to securitize changed when the ECB started providing liquidity facilities in the aftermath of the financial crisis.

Another transformative element of post-crisis ECB policies is Quantitative Easing (QE). This monetary programme started in 2014 and was expanded in 2015 to include securitized assets. Unlike the conventional role for central banks, which saw them operating as a "buyer of last resort' in order to maintain liquidity in the banking sector when the market evaporates as a result of a loss in confidence, QE was a policy of 'buyer of first resort' in resuscitating a dead market. QE purchases of securitized assets come on top of retained securitizations, which serve as collateral to ECB's liquidity programmes.

Focusing on the securitization proposal of the $\mathrm{CMU}$, we find additional concerns. First, the proposal only focuses on the securitization process and ignores the quality of the underlying collateral, stating explicitly: "The concept of 'simple, transparent and standardised' (STS) refers to the process by which the securitisation is structured and not the underlying credit quality of the assets involved" (European Commission, 2015b: 3). While the political legitimation of the CMU centres on providing credit to SMEs, there is no safeguard in the STS proposal that mortgages will not receive most of the capital allocated through Europe's new securitization infrastructure. This absence of requirements regarding the collateral used in the STS process is the chief motivation for us to believe that this new financial infrastructure will result in an increase in housing finance. In 2016, 56\% of all securitizations in Europe had mortgages as collateral and 6\% SME debt (AFME, 2016b: 6). It is striking that 'SME' features 49 times in the CMU green paper (Engelen and Glassmacher, 2016) and 'mortgages' only once (European Commission, 2015a: 10). The Bank of England (2015: 12) made the following assessment: 
Notably, securitisations backed by SME loans are only a small proportion of issuance in both Europe and the United States, and are supported to an extent in both jurisdictions by publicly funded guarantees. It remains to be seen whether attempts to revive the securitisation markets, for example, by developing criteria to identify securitisations that are simple, transparent and comparable, will have a significant impact on the sharing of risks from SMEs and hence on SME lending.

The process of STS securitization includes the following requirements: (1) securitized assets must be homogenous; (2) there must be a credit history for underlying assets to assess default risk; (3) loans must be owned by the originator; (4) documentation requirements must be fulfilled; and (5) the originating bank must retain $5 \%$ of securitized assets. The first requirement favours mortgages over SME loans, as the latter typically involve unique transactions.

If we focus on mortgages, the absence of any assessment of the quality of the collateral or the origination process, beyond comparability and credit history, is inexplicable in light of the lessons of 2007. The aim of the STS proposal is to lower capital requirements for banks involved with securitization, but fails to provide a framework to assess the quality of underlying loans. This contrasts to reforms proposed by the IMF, which stress how "the quality of underlying loan origination practices should be further beefed up to restore the appetite for securitization" (IMF, 2015: 4). In other words, while the STS proposal does lower the capital requirements for banks, making it cheaper to have STS assets on the balance sheet, it fails to specify the quality of the underlying collateral.

STS securitization does not include any safeguards beyond increasing the quality of reporting, transparency, and comparability. These are all elements of market making, but fail to deliver on linking the type of debt with the overarching intermediation process: the achilles heel of finance in 2007 (Turner, 2012). Moreover, the STS proposal includes derivatives and tranching as part of the securitization practice, in effect making the process anything but simple (Finance Watch, 2015; Engelen and Glasmacher, 2016).

Finally, the STS proposal opens the door to include synthetic securitization (securitization without collateral), such as colleterized debt obligations (CDOs), in the future. Although the proposal stresses that the STS label will be reserved only for 'true sale' securitization, the proposal also includes the following section:

Until now neither on an international level (BCBS-IOSCO), nor on a European level (EBA), have STS criteria been developed for synthetic securitisation. Thus at this moment there is insufficient clarity on which synthetic securitisations should be considered STS and under which conditions. The Commission will further consider this issue and follow the work of international and European bodies on this topic. It will assess whether some synthetic securitisations that have performed well during the financial crisis and that are simple, transparent and standardised should be able to meet the STS requirements. Future input from in particular the EBA could inform the Commission in its future policy proposals. (European Commission, 2015b: 15)

This leaves a backdoor open to integrate CDOs in a future STS label, reflecting the aggressive pressure from financial market lobby groups in the CMU process.

In essence, STS has been reduced to nothing less than an empty signifier: simplicity, transparency, and safety were all dropped in favour of more securitization in more markets for more types of mortgages. Apparently, the European market for securitization needs to be revived - indeed, expanded - at all cost. Since 'the market' is unable to revive itself, the state (and in this instance the supranational state of the EU) is being mobilized to make this happen. 


\section{Conclusion}

The securitization of mortgage loans is widely credited for contributing to the global financial crisis. Not only did securitization result in the interdependence of housing and financial markets around the globe, it was also key to the expansion of shadow banking. Housing loans were first repackaged in residential mortgage-backed securities (RMBS) and subsequently at the basis of a long chain of synthetic derivatives products that were the very opposite of 'simple, transparent and safe'. It was no surprise that securitization fell rapidly as the financial crisis spread globally, but it also came back in fashion only a few years later, albeit very unevenly geographically speaking (Aalbers and Engelen, 2015). The current monetary policy of the ECB that includes the direct purchase of securitized assets re-accommodates growing private debt and we expect that the CMU will take this to another level.

We argue that the $\mathrm{CMU}$ may result in the rescaling of the existing national mortgage markets and create a pan-European market for mortgages, or at least for RMBS. This is not a 'capital market' solution to a weak EU banking system, as the European Commission claims in defence of the $\mathrm{CMU}$, but increasingly seems to be a publicly manufactured asset bubble spreading across the EU. Our main argument is that the increase in credit is likely to flow to countries that as-of-yet have low levels of housing-centred financialization. This argument builds on previous research (Fernandez and Aalbers, 2016) into trajectories of housingcentred financialization, which shows how some countries appear saturated with housing finance while others are still in the early stages of housing-centred financialization. The goal of the EU Commission is not to create a safer primary or secondary mortgage market for borrowers and lenders, but rather to rollout the technique of securitization across the EU, thereby pushing housing-centred financialization onto countries with hitherto relatively low levels of mortgage debt or securitization. However, this process of supranational market making needs time to institutionalize, as new channels of financial intermediation and new asset classes for institutional investors do not develop overnight.

We know that social scientists should refrain from forecasting. Yet, we recognize that, once an economy is drawn into a manic period, credit-fuelled housing bubbles can develop rapidly. Kindleberger and Aliber (2000) speak of different locations in different periods across different models of capitalism, all bound by housing bubbles fuelled by cheap credit. If we consider Spain, Ireland, the UK, and the Netherlands, we need to conclude that these countries, formerly firmly embedded in a wage-led accumulation regime characterized by low levels of mortgage debt, transformed quickly. Within two decades, an interrelated institutional ensemble emerged that was debt-driven and dependent on foreign capital, growing levels of homeownership, and supportive policies that liberalized housing finance - with dramatic consequences.

The use of housing wealth as financial accelerator is politically addictive and has proven, in countries such as Spain and Ireland, to be able to completely overhaul the model of residential capitalism in a decade. Once established, increasing numbers of households rely on rising housing wealth in a regime of housing-centred financialization, with electoral preferences shifting towards favouring the continued liberalization of housing finance. Privatized Keynesianism becomes firmly rooted in the political economy. Since the financial crisis, we have seen that where there has been some moving away from housing-centred financialization, it has above all been through a contradictory process in which a rise in private landlordism and private equity funds create new patterns of winners and losers (Fields and Uffer, 2016; Ronald et al., 2015; Wijburg and Aalbers, 2017; Arundel, 2017). We are only now starting to understand how economies move from low to high debt, but we do not yet 
understand how to manage a reversal: a process of deleveraging and deflating house prices.

While the economic justifications for the CMU in its current form and in the current context are highly questionable, there is something more sinister at work. The underlying decision-making apparatus that generates and sells the CMU is showing 'post-democratic' signs and is increasingly turning into the showpiece of a captured technocratic mode of governance of the EU superstructure. Engelen and Glasmacher (2016) use the metaphors of 'frontstage' and 'backstage' to describe the CMU's post-democratic policymaking. They highlight the discrepancy between the frontstage narrative, focused on SME and jobs, and the actual backstage law making, focused on lowering the capital costs for old-school securitization.

While the European Parliament and the media are distracted by the SME narrative, the core issue - that is, the housing-centred model of financialization it promotes and the systemic risks associated with securitization and housing bubbles - is kept out of the debate. Expanding the housing-centred model means that we are on an unsustainable path. In this model, claims on future income and production are used to solve today's lack of effective demand. This can only be stretched so far. Moreover, giving securitization a central role in financial intermediation in the EU wilfully ignores the systemic risks of the shadow banking system. These fundamental properties of the CMU should be central to the debate if we are to break the post-democratic grip on the economic narratives of the European Commission.

\section{Acknowledgments}

The work of the authors is part of 'The Real Estate/Financial Complex' research project [http://ees.kuleuven.be/refcom], which is supported by the European Research Council [grant no. 313376]. The authors would like to thank the referees, Rowan Arundel, and members of their research group for comments on earlier versions of this manuscript.

\section{Notes}

1. This index measures differences in housing finance systems. It includes how housing wealth can be used for consumption, by looking at the possibilities for mortgage equity withdrawal schemes and the ease of refinancing. It also measures the credit restrictions for households by incorporating the typical loan-to-value and the average term. A third element is the use of nonbank financing channels, such as covered bonds and securitization. These three domains are condensed into an index ranging from 0 to 1.

2. On the offshore geography of European based SPVs, see Fernandez and Wigger (2017).

\section{References}

Aalbers, M.B. (2008) The financialization of home and the mortgage market crisis. Competition and Change, 12(2): 148-66.

Aalbers, M.B. (2015) The great moderation, the great excess and the global housing crisis. International Journal of Housing Policy, 15(1): 43-60.

Aalbers, M.B. (2016) The Financialization of Housing: A Political Economy Approach. London: Routledge.

Aalbers, M.B. and Christophers, B. (2014) Centering housing in political economy. Housing, Theory and Society, 31(4): 422-28. 
Aalbers, M.B. and Engelen, E. (2015) The political economy of the rise, fall, and rise again of securitization. Environment and Planning A, 47(8): 1597-1605.

Aalbers, M.B., Engelen, E. and Glasmacher, A. (2011) 'Cognitive closure' in the Netherlands: Mortgage securitization in a hybrid European political economy. Environment and Planning A, 43(8): 177995.

AFME (2016a) AFME Securitization Data Report: European Structured Finance 2016 Q2. Brussels: Association for Financial Markets in Europe.

AFME (2016b) AFME Securitization Data Report: European Structured Finance 2016 Q3. Brussels: Association for Financial Markets in Europe.

Arundel, R. (2017) Equity inequity: Housing wealth inequality, inter and intra-generational divergences, and the rise of private landlordism. Housing, Theory and Society, 34(2): 176-200.

Bank of England (2015) A European Capital Markets Union: Implications for growth and stability. Bank of England Financial Stability Paper No. 33.

BIS (2006) Housing finance in the global financial market. CGFS Paper, No 26.

BIS (2011a) The development of securitisation statistics in Ireland. IFC Bulletin No. 34.

BIS (2011b) Report on Asset Securitisation Incentives. Basel: Bank of International Settlements.

BIS (2012) The great leveraging. BIS Working Papers, No 398.

BIS (2013) Mind the Gap? Sources and Implications of Supply Demand Imbalances in Collateral Asset Markets. Basel: Bank of International Settlements.

Boyer, R. (2000) Is a finance-led growth regime a viable alternative to Fordism? A preliminary analysis. Economy and Society, 29(1): 111-45.

Brenner, N., Peck, J. and Theodore, N. (2010) After neoliberalization? Globalizations, 7(3): 327-45.

Buchanan, B.G. (2017) Securitization and the Global Economy: History and Prospects for the Future. Basingstoke: Palgrave Macmillan.

Crouch, C. (2009) Privatised Keynesianism: An unacknowledged policy regime. British Journal of Politics and International Relations, 11(3): 382-99.

Di Feliciantonio, C. (2016) Subjectification in times of indebtedness and neoliberal/austerity urbanism. Antipode, 48(5): 1206-27.

DNB (2000) Het bancaire hypotheekbedrijf onder de loep. Rapport over de ontwikkelingen op de hypotheekmarkt in de periode 1994-1999 gebaseerd op onderzoek naar de hypothecaire kredietverlening bij Nederlandse financiële instellingen. Amsterdam: De Nederlandsche Bank.

ECB (2016) Survey on the Access to Finance of Enterprises in the Euro Area: October 2015 to March 2016. Frankfurt: ECB.

ECB Monetary and Financial Statistics (n.d.) Available at: $<$ https://www.ecb.europa.eu/stats/money/fvc/html/index.en.html/>. Accessed 10 November 2016.

EMF data (n.d.) Available at: <http://www.hypo.org/Content/default.asp?PagelD=414/>. Accessed 20 May 2015.

Engelen, E. (2008) The case for financialization. Competition and Change, 12(2): 111-19.

Engelen, E. and Glasmacher, A. (2016) 'Simple, transparent and standardized': Narratives, law and interest coalitions in regulatory capitalism. Unpublished working paper. Available at: $<$ https://www.researchgate.net/publication/302536200_Simple_Transparent_and_Standardized _Narratives_Law_and_Interest_Coalitions_in_Regulatory_Capitalism/>. Accessed 8 January 2017. EPRA (2012) Real estate in the real economy: Supporting growth, jobs and sustainability. European Public Real Estate Assocation. Available at: <http://www.epra.com/application/files/8415/0392/6698/INREV_EPRA_Real_Estate_Real_Econ omy_2016_Report.pdf/>. Accessed 2 October 2017. 
Eurostat data (n.d.) Available at: <http://ec.europa.eu/eurostat/statisticsexplained/index.php/Housing_statistics/nl\#Eigendomssituatie/>. Accessed 9 March 2016.

European Commission (2012) Green Paper: Shadow Banking. Brussels 19.3.2012 COM (2012) 102 final.

European Commission (2015a) Green Paper: Building a Capital Markets Union. Brussels 18.2.2015 $\operatorname{COM}(2015) 63$.

European Commission (2015b) Proposal for a REGULATION OF THE EUROPEAN PARLIAMENT AND OF THE COUNCIL laying down common rules on securitization and Creating a European framework for simple, transparent and standardized securitization and amending Directives 2009/65/EC, 2009/138/EC, 2011/61/EU and Regulations (EC) No 1060/2009 and (EU) No 648/2012. Brussells. Available at: <http://eur-lex.europa.eu/legalcontent/EN/TXT/PDF/?uri=CELEX:52015PC0472andfrom=EN/>. Accessed 8 January 2017.

Fernandez, R. and Aalbers, M.B. (2016) Financialization and housing: Between globalization and varieties of capitalism. Competition and Change, 20(2): 71-88.

Fernandez, R. and Wigger, A. (2016) Lehman Brothers in the Dutch offshore financial centre: The role of shadow banking in increasing leverage and facilitating debt. Economy and Society, 45(3-4): 407-30.

Fields, D. and Uffer, S. (2016) The financialisation of rental housing: A comparative analysis of New York City and Berlin. Urban Studies, 53(7): 1486-1502.

Finance Watch (2014) A missed opportunity to revive "boring" finance? A position paper on the long term financing initiative, good securitisation and securities financing. Brussels: Finance Watch.

Finance Watch (2016) Have the lessons from the financial crisis been learned? Statement at European Parliament's ECON Committee Public Hearing on Securitisation, 13 June, Brussels. Available at: <http://www.europarl.europa.eu/cmsdata/103512/2016\%2006\%2013_STS_hearing_FW_openin g_statement\%20final_Nijdam.pdf/>. Accessed 2 October 2017.

Forrest, R. and Hirayama, Y. (2015) The financialisation of the social project: Embedded liberalism, neoliberalism and home ownership. Urban Studies, 52(2): 233-44.

FSB (2011) Shadow Banking: Scoping the Issues. Basel: Financial Stability Board.

FSB (2015) Global Shadow Banking Monitoring Report 2015. Basel: Financial Stability Board.

Gotham, K.F. (2009) Creating liquidity out of spatial fixity: The secondary circuit of capital and the

subprime mortgage crisis. International Journal of Urban and Regional Research, 33(2): 355-71.

Hacker, J. (2008) The Great Risk Shift. Oxford: Oxford University Press.

Harvey, D. (2005) Neoliberalism: A Brief History. Oxford: Oxford University Press.

Hudson, M. (2012) The Bubble and Beyond: Fictitious Capital, Debt Deflation and Global Crisis. Dresden: ISLET.

IMF (2011) Housing finance and financial stability: Back to basics. In: IMF Global Financial Stability Report 2011. Washington, DC: IMF.

IMF (2011a) Institutional cash pools and the Triffin Dilemma of the U.S. banking system. IMF Working Paper 11/190.

IMF (2011b) The nonbank-bank nexus and the shadow banking system. IMF Working Paper 11/289.

IMF (2013) Fiscal Monitor: Taxing Times. Washington, DC: IMF.

IMF (2015) Securitization: The road ahead. IMF Staff Discussion Note, SDN/15/01.

Immergluck, D. (2009) Re-forming Mortgage Markets: Sound and Affordable Home Lending in a New Era. Ithaca, NY: Cornell University Press.

Jones, C. and Murie, A. (2006) The Right to Buy: Analysis and Evaluation of a Housing Policy. Oxford: Blackwell. 
Jorda, O., Schularick, M. and Taylor, A.M. (2014) The great mortgaging: Housing finance, crises, and business cycles. Federal Reserve Bank of San Francisco Working Paper 2014-23. Available at: <http://www.frbsf.org/economic-research/files/wp2014-23.pdf/>. Accessed 29 July 2016.

Kemeny, J. (1981) The Myth of Home Ownership. London: Routledge and Kegan Paul.

Kindleberger, C.P. and Aliber, R.Z. (2000) Manias, Panics and Crashes. New York, NY: Palgrave Macmillan.

Lapavitsas, C. (2013) The financialization of capitalism: 'Profiting without producing'. City, 17(6): 792 805.

Langley, P. (2006) Securitising suburbia: The transformation of Anglo-American mortgage finance. Competition and Change, 10(3): 283-99.

Lazzarato, M. (2012) The Making of the Indebted Man: An Essay on the Neoliberal Condition. Cambridge, MA: MIT Press.

Martin, R. (2002) Financialization of Daily Life. Philadelphia, PA: Temple University Press.

McKinsey. (2013) QE and ultra-low interest rates: Distributional effects and risks. McKinsey Global Institute, November 2013. Available at: <https://www.mckinsey.com/global-themes/employmentand-growth/qe-and-ultra-low-interest-rates-distributional-effects-and-risks/>. Accessed 3 October 2017.

Mueller, J. (2015) European Capital Markets Union: False promises of growth and risks to financial stability? SOMO Paper, September 2015. Available at: <https://www.somo.nl/wpcontent/uploads/2015/09/European-Capital-Markets-Union.pdf/>. Accessed 8 January 2017.

OECD (2010) Real house prices in OECD countries: The role of demand shocks and structural and policy factors. OECD Economics Department Working Papers, No. 831.

OECD (2011) Outlook for the securitisation market. OECD Journal: Financial Market Trends, Volume 2011: 1-18.

Piketty, T. (2014) Capital in the Twenty-First Century. Cambridge, MA: Harvard University Press.

Polanyi, K. (2001/1944) The Great Transformation: The Political and Economic Origins of Our Time. Boston, MA: Beacon Press.

Pozsar, Z., Adrian, T., Ashcroft, A., and Boesky, H. (2012) Shadow Banking. Federal Reserve of New York Staff Report No. 458.

PwC (2016) Securitisation in Luxembourg: A Comprehensive Guide. Luxembourg: PricewaterhouseCoopers.

Rolnik, R. (2013) Late neoliberalism: The financialization of homeownership and housing rights. International Journal of Urban and Regional Research, 37(3): 1058-66.

Ronald, R. (2008) The Ideology of Home Ownership: Homeowner Societies and the Role of Housing. Basingstoke: Palgrave Macmillan.

Ronald, R., Lennartz, C. and Kadi, J. (2015) Homeownership-based welfare in transition. Critical Housing Analysis, 2(1): 52-64.

Schwartz, H.M. (2009) Subprime Nation: American Power, Global Capital, and the Housing Bubble. Ithaca, NY: Cornell University Press.

Schwartz, H.M. (2012) Housing, the welfare state, and the global financial crisis: What is the connection? Politics and Society, 40(1): 35-58.

Schwartz, H. and Seabrooke, L. (2008) Varieties of residential capitalism in the international political economy: Old welfare states and the new politics of housing. Comparative European Politics, 6(3): 237-61.

Streeck, W. (2016) How Will Capitalism End? Essays on a Failing System. London: Verso.

Stiglitz, J.E. (2016) The Euro: How a Common Currency Threatens the Future of Europe. New York, NY: W.W. Norton and Company. 
Stockhammer, E. (2004) Financialisation and the slowdown of accumulation. Cambridge Journal of Economics, 28(5): 719-41.

Turner, A. (2012) Shadow banking and financial instability. Speech given at Cass Business School, 14 March.

UNCTAD (2013) Trade and Development Report, 2013. Geneva: UNCTAD.

Wainwright, T. (2009) Laying the foundations for a crisis: Mapping the historico-geographical construction of residential mortgage backed securitization in the UK. International Journal of Urban and Regional Research, 33(2): 372-88.

Wainwright, T. (2015) Circulating financial innovation: New knowledge and securitization in Europe. Environment and Planning A, 47(8): 1643-60.

Walks, A. and Clifford, B. (2015) The political economy of mortgage securitization and the neoliberalization of housing policy in Canada. Environment and Planning A, 47(8): 1624-42.

Wijburg, G. and Aalbers, M.B. (2017) The alternative financialization of the German housing market. Housing Studies, 32(7): 968-89. 